\title{
THE
}

\section{Présents du Roi: An Archive at the Ministry of Foreign Affairs in Paris}

\author{
Corinne Thépaut-Cabasset
}

Pamela J. Warner

University of Rhode Island, pwarner@mail.uri.edu

Follow this and additional works at: https://digitalcommons.uri.edu/art_facpubs

Terms of Use

All rights reserved under copyright.

\section{Citation/Publisher Attribution}

Thépaut-Cabasset, Corinne. "Présents du Roi: An Archive at the Ministry of Foreign Affairs in Paris." Translated by Pamela J. Warner. Studies in the Decorative Arts 15 (2007): 4-18.

Available at: http://www.jstor.org/stable/10.1086/652842.

This Article is brought to you for free and open access by the Art and Art History at DigitalCommons@URI. It has been accepted for inclusion in Art and Art History Faculty Publications by an authorized administrator of DigitalCommons@URI. For more information, please contact digitalcommons@etal.uri.edu. 
CORINNE THÉPAUT-

CABASSET

\section{Présents du Roi: An Archive at the Ministry of Foreign Affairs in Paris}

In his Siècle de Louis XIV (1752), Voltaire insisted several times on the importance of gifts made by the king, both in national affairs and in his relations with European countries. The savant called them the trademark of Louis XIV's century and wrote that what "gave him the most splendor in Europe was the generosity that had no model. ... The presents made to foreign countries were so considerable that Viviani had a house built in Florence for the magnanimous gifts of Louis XIV. He put in golden letters on the entry: Aedes a deo datae, an allusion to the nickname Dieudonné [God-given] that the public had given to this prince at his birth." The meaning given to the word "present" is important, because it emphasized the king's gesture of bestowing the gift. In his treatise of 1676, L'Ambassadeur et ses fonctions, Abraham de Wicquefort asserted that "the question of gifts is an important one." In his Dictionnaire universel, published in 1690, Antoine Furetière defined the "present" as a "free gift," a "favor," a "recognition," that is to say, a "mark of esteem or of friendship," and the author illustrated this definition with the statement that "Kings make great presents to ambassadors," and that "one hardly approaches Oriental kings without offering them beautiful presents." The term comes from praesentia, "because one must give them into the hands of a person [who is] present."3

Documenting the extraordinary extent and magnificence of the gifts given by Louis XIV is a manuscript held in the archives of the Ministry of Foreign Affairs in Paris. ${ }^{4}$ "Receuil [sic] des présents faits par le Roy. En pierreries, meubles, argenterie et autres, depuis l'année 1662 jusque et compris l'année 1721" (Registry of the gifts made by the King in precious gems, furniture, silver and others, from the year 1662 up to and including the year 1721) (Figs. 1-4) is the first of a series in the archives that chronologically registers royal gifts. This series, classified as Mémoires et documents, France, Présents du roi, consists of sixty volumes that cover the period of the reigns of Louis XIV through Louis XVI. ${ }^{5}$ The Mémoires et documents series is numerically one of the largest holdings in the Ministry of Foreign Affairs. Prior to the Revolution, these documents were des-

Corinne Thépaut-Cabasset is a researcher at the Research Center of the Château de Versailles and a Ph.D. candidate in the history of international and European relations at the University of Paris IV-Sorbonne. 
ignated under the vague term "manuscripts."6 Afterward it was understood that, classified by subject, they made a most varied complement to the Ministry's archive of political papers. Following the same principle that organizes the Correspondance politique series and annexed to it, Les Présents du roi is divided into geographic chapters where documents relating to a given country are grouped together.

The Mémoires et documents also includes a collection that holds a unique place among the other series at the Foreign Affairs Ministry: the fonds France, which includes a large number of documents, certain of which date back to the sixteenth century, or earlier, and which concerns business internal to France and the administration of the provinces, multilateral negotiations, and international conferences. It is here that are found the bulk of the papers of cardinals Richelieu and Mazarin, those of the comte de Saint-Simon, and the memoirs of the marquis de Dangeau, as well as documents concerning royal ceremonies and protocol, the king's presents, and the historical work of the keepers of the archives and certain of the king's historiographers. Of the major interests of the particular volume studied here is its site of preservation, for its classification in a series of thematic archives within the Mémoires et documents, France implies that it was seen as a record of precedents for foreign politics.

\section{The Recueil Dubois}

As a reference document, the volume under consideration here appears to be the most complete and best organized record of the Présents $d u$ roi. In fact, this manuscript of 244 folios carries at its end an "Alphabetical index of presents that were given by the king to ambassadors and other people," listing the names of places (organized alphabetically by country or municipality), the occasions on which the presents were given (Baptisms of the Children of France [the royal children], Battles, Illnesses, Marriages, Births of Princes, Peace, Prix de Carrousel, Taking of Cities), salaries, the name of the beneficiary (a Chancellor, Negotiators, Officers, Individuals), and of the objects (such as portraits of the king painted in oil). This index helpfully uses the titles of different chapters of the compendium.

The volume, composed of chapters, is divided into two parts: first Europe, from Sweden to Turkey, then Asia and other countries designated "de Nègres," meaning Africa, the Americas, and other places where nonwhite people lived. The chapters review by country and year by year the presents given by "His Majesty" on all sorts of occasions and 

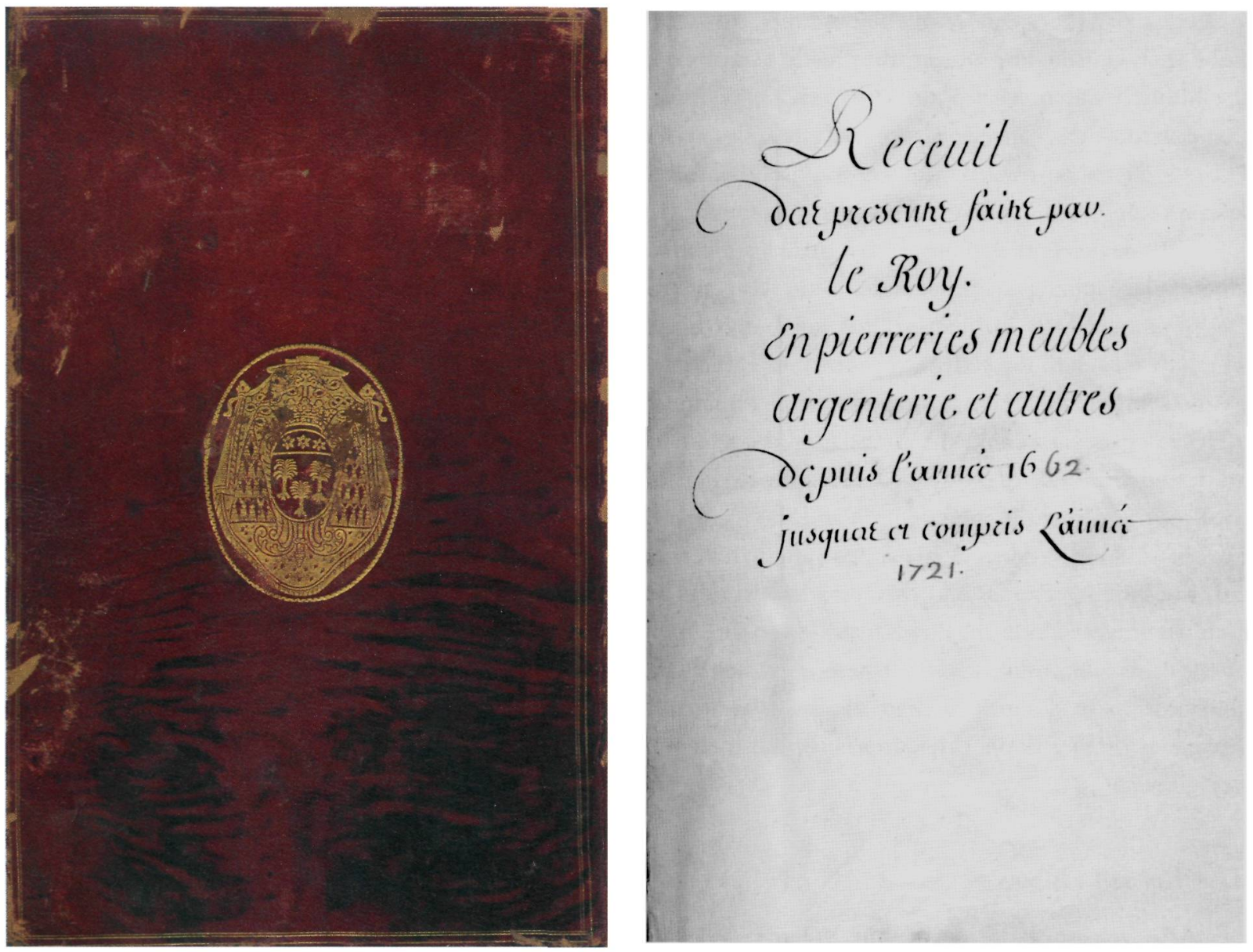

\section{FIGURE}

"Receuil [sic] des présents faits par le Roy. En pierreries, meubles, argenterie et autres, depuis l'année 1662 jusque et compris l'année 1721," 1721, front cover. Ministère des Affaires Étrangères, Paris, Mémoires et documents, France (Présents du roi, vol. 1), 2037.

\section{FIGURE 2}

"Receuil des présents faits par le Roy," title page. subjects. The only gifts registered are those given by the king of France, as the incarnation of the nation-state, to foreign ministers, ambassadors, residents, their secretaries, individuals, artists, writers, mathematicians, officers of his government, and to "the Children of France." Almost no present given to another king is included in this registry; in fact, this type of king-to-king gift does not seem to have been the object of the same systematic compilation, for reasons that are not yet clear.?

This carefully crafted manuscript is bound in red leather stamped with the coat of arms of Cardinal Guillaume Dubois (Fig. 1), which can be read as follows, according to conventional armorial language: $d$ 'argent à trois arbres sinople, rangés sur une terrasse du milieu plus haut que les deux autres, et un chef d'azur de trois étoiles d'or (in silver with three sinople trees, arranged on a terrace of the same, the middle one being higher than the two others, and an azure crest with three golden stars). On 

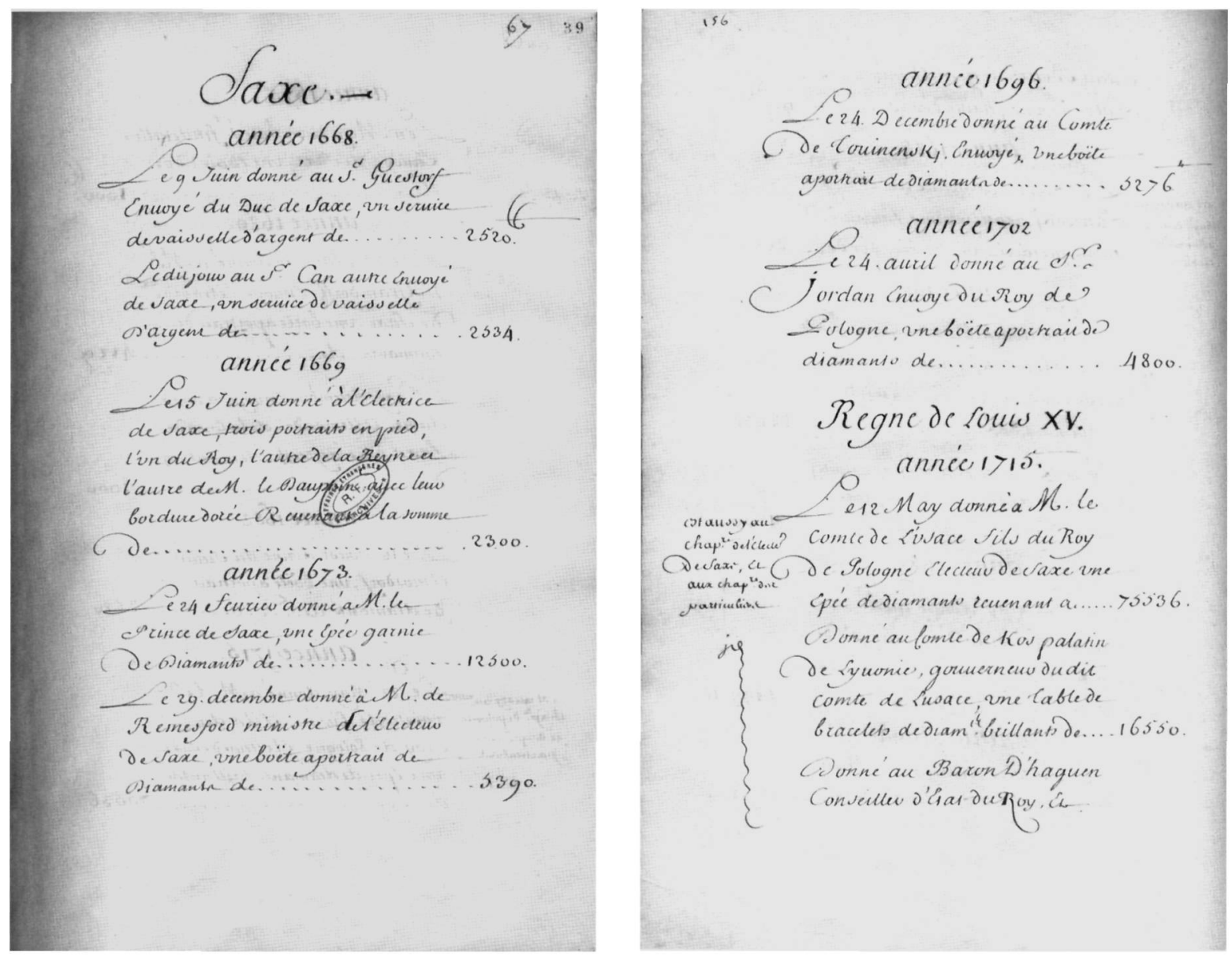

September 1, 1718, Cardinal Dubois succeeded Jean-Baptiste Colbert de Torcy as minister of foreign affairs and in 1722 he was named prime minister of France (he became a cardinal in 1721). The binding of the Dubois recueil is important for its proprietary meaning: ${ }^{8}$ under Louis XIV, it was standard practice for ministers of France to have their own coats of arms embossed on volumes of state papers. In 1680 Charles Colbert, marquis de Croissy (1625-1696; Secretary of State for Foreign Affairs 1679-1696; brother of Jean-Baptiste Colbert [1619-1683], Louis XIV's chief minister), had his coat of arms embossed on the bindings of papers documenting state negotiations, likewise an affirmation of ownership. Similarly, in 1690 François-Michel Le Tellier, marquis de Louvois, Minister of War (1677-1691), assembled dossiers concerning the War Department and had them bound with his coat of arms. This practice of
FIGURES $3-4$

Registry of gifts to duchy of Saxony, "Receuil des présents faits par le Roy," fol. $1 \mathrm{r}-\mathrm{v}$. 
asserting ownership of state papers gave way over time to the application of the royal coat of arms on bindings. ${ }^{9}$

The embossing of the seal of Cardinal Dubois on the volume Présents $d u$ roi thus indicates his sense of ownership from the moment of its creation; moreover, it gives the volume a supplemental value for bibliophiles. It can be assumed that this volume was composed for Cardinal Dubois during his tenure as Secretary of State for Foreign Affairs (17181722, then Prime Minister) and that the coat of arms embossed on it, like Colbert de Croissy's for his own papers, attests to the function and importance that Dubois wished to give this reference document at the time.

In the sixty-volume series of the Présents $d u$ roi, it should be noted that only the first volume is bound with Dubois's coat of arms. Some of the other volumes are bound in white parchment: they may be defined as the documentation used for the elaboration of the first volume, and they come very probably from the papers of the "steward" or the "keeper of the king's precious gems." The other volumes that follow in this numerical series are bound in plain red leather with the seal of France.

It should be noted that two other versions of this manuscript exist and contain some differences in information. A copy held in the department of French manuscripts at the Bibliothèque Nationale de France, in two volumes bound in white parchment, contains blank pages intended for future completion in each volume: it is in fact an unfinished work. Its title, "Receuil des présents faits par le roi en pierreries, meubles, argenteries et autres à commencer de l'année 1669 jusque et compris l'année 1714" [The Gifts of the King in precious gems, furniture, silver and others, from the year 1669 up to and including the year 1714], specifies: "Sauf à y ajouter ceux qui seront faits dans les années suivants" [Except those which will be made in the coming years]. A notice at the beginning of the first volume indicates that "an individual offered the documents that he had gathered, finding himself in the position to make two volumes of them. Which begin from the year 1669 up to and including the present year 1714. And when there are more, he will augment them with that which comes to his attention." 10 This handwritten manuscript is anonymous. It was composed by "an individual," a man from the cabinet, in 1714 with documents not earlier than 1669 and dating to 1714 (whereas the Dubois volume can be dated by documents beginning in 1662 and extending to 1721).

Another copy, in the Bibliothèque de l'Arsenal, ${ }^{11}$ seems identical to that kept by Dubois at the Foreign Affairs Ministry. In the same format, it is a single volume of 233 folios, bound in brown vellum without a seal; 
it includes an index. It is unclear which volume was the original, which the copy. The Arsenal volume was part of the collection "Histoire, $\mathrm{n}^{\circ}$ 4414 C" of the marquis de Paulmy's library. ${ }^{12}$ On the last page, "Mondolot" is written in ink. Here again, it is very difficult to trace its origins or to know who the author is.

\section{Archiving Governmental Memory}

The Department of Foreign Affairs was created at the instigation of Charles Colbert, marquis de Croissy (Secretary of State for Foreign Affairs 1679-1696). During the reign of Louis XIV, centralized administration became the necessary instrument of central state power, and the secretaries of state constituted the administrative machinery that prepared and executed royal decisions. ${ }^{13}$ The creation of state depositories coincided with the centralization and reorganization efforts of the age of the Sun King. In 1680, Jean-Baptiste Colbert, Louis XIV's chief minister, had papers from these two administrations gathered and classified in a warehouse probably then in Saint-Germain-en-Laye. Care of this archive was entrusted to Pierre Clairambault, clerk for the Navy, who later shared his erudition with the Secretary of State for Foreign Affairs.

This became the depository for the Ministry of Foreign Affairs established by Colbert de Torcy. After the state council session of December 22, 1709, de Torcy noted in his journal: "His Majesty was pleased, about that which I explained to him, to donate a space in the Louvre as a depository for all the important Foreign Affairs papers." ${ }^{14}$ In 1710, Yves de Saint-Prez (or Saint-Prest), a member of the state council, was named the keeper of the depository. The appointment of this keeper or director fell to the Secretary of State, as did that of all the first clerks. Throughout the Ancien Régime the depository was considered a division (or office) of the Secretary of State.

Parallel to this, in April 1712, de Torcy created a political academy in the staterooms of the Old Louvre, in order to prepare young men called to foreign service; and the papers of the academy were added to the foreign ministry archives, in order to create a corpus of documents on French diplomatic history. This idea was not new: at the beginning of Louis XIV's reign there had been a plan to create a college for diplomats where forty young men, twenty from the first families of the kingdom, would be educated. The school, called the Collège des Quatre Nations, was finally created in 1688. De Torcy envisioned a school that would have at its core "le dépôt des affaires étrangères" and its students would be "Messieurs du Cabinet." The depository would be a set of documents 
composed of extracts and copies, classified and put in order to be used, of "all the titles and papers concerning the duties of the Ministry of State for Foreign Affairs," and would preserve the papers of former ministers. ${ }^{15}$ As Armand Baschet has written: "Torcy added a capital idea to that of creating a depository of foreign affairs, which was that of a negotiating school, that of a center for study as specially applied to politics as a military school could be to the art of war." 16 The depository, or "cabinet du Louvre," 17 became the place for exercises and practical tasks for the students, the "Messieurs du Cabinet," according to the "Project for study" of Minister Torcy. When the manuscript collector François-Roger de Gaignière (1662-1715) died and his collection of manuscripts was considered for acquisition by the king's librarian Pierre Clairambault, the genealogist of the Orders of the King, he asked for the help of several of the "Messieurs du Cabinet" in examining those manuscripts dealing with negotiations and ambassadors. ${ }^{18}$

De Torcy's successor, the Abbot Dubois (he became cardinal only in 1721), lacking time to enact reforms, denied the students of the political academy access to the depository when its director Saint-Prez died in 1720. Under Dubois, who suppressed the academy, the depository became a department of historical records, accessible to those researching state doctrines, erudition, and historical matters. Nicolas-Louis Le Dran was the director until $1740 .{ }^{19}$

Dubois was nonetheless preoccupied by the organization of and access to the archival holdings of the Foreign Affairs Ministry: as such he was interested in the customs of other European nations and in the training of future ambassadors. This is why he sought out the king's ministers, residing for the most part in countries having relations with France. In September 1721, he carried on a correspondence with Sir Frémont, the French Resident (a diplomatic title) in Venice: ${ }^{20}$

I beg of you not to forget to indicate whether or not there is a depository where one keeps papers that concern the affairs of the Republic with foreigners, and to give me the details of everything about it, that is to say the order that is followed there, to whom this depository is entrusted, who are the officers who take care of it and everything that could give an exact description. ${ }^{21}$

In addition to the "Archivio Segreto" (secret cabinet) in Venice, other foreign affairs depositories of this type existed elsewhere in Europe at the same time, for example, the State Papers Office in England. It is clear, then, that the Dubois volume is an excellent reflection of what was desired at the time-a historical resource for foreign affairs. 


\title{
Forming the Présents du roi Volumes
}

Concerning the formation of the volumes of the Présents $d u$ roi, Pierre Clairambault is an interesting contemporary source. As Philippe Lauer wrote in 1923 ,

\begin{abstract}
Born in Asnières in 1651, [Clairambault] began his career in Colbert's library, then in that of the King, under the direction of Pierre Carcavy. In 1676, [and] then in 1683, he was asked to lend his support to [Jacques-Bénigne] Bossuet and to [François de Saligne de la Mothe] Fénelon for the historical instruction of the son and grandson of Louis XIV, and he undertook a compilation. [By this] researcher and compiler, his volumes, which constitute his collection at the Bibliothèque Nationale today, include extracts taken from manuscripts in the king's library, but also copies or extracts accompanied by original documents from the sixteenth and seventeenth centuries... The well-earned fame that he acquired led him to be designated in 1698 as genealogical director for the Orders of the King. ... He excelled at organizing documents into volumes following the system most likely to facilitate their use. ${ }^{22}$
\end{abstract}

Clairambault, in sum, handled a large group of archives related to the volumes of royal gifts. A manuscript in the Clairambault collection, entitled Mémoires concernant les pierreries du Roi [Memoirs about the King's precious gems] indicates that the origin and classification of papers should follow "the order followed in keeping books of precious gems."23 This manuscript is interesting in that it reveals the existence of these books, or "registers and public papers," which could have been those put together and stored in the archives of the Ministry of Foreign Affairs. ${ }^{24}$ The description of Clairambault's work and methods seems close to the work carried out to produce the volumes of the king's presents. The French manuscript of the Bibliothèque Nationale de France was made by "un particulier" (a certain individual)25: could it have been Pierre Clairambault? It can be assumed, or at least hypothesized, that at the very least the Dubois volume was elaborated according to Clairambault's principles.

With historical data gathered into chapters, the volumes of gifts are a compilation of a variety of documents: memoranda, papers, extracts, inventories, and journals, which aspire to resemble an organized sample. They also express the desire of the era to organize memory, to control a complex and difficult-to-consult collection of accounting documents, on the model of that handled by another institution, the Garde-Meuble. These "Inventories," "Journals," and "Books," all extracts of the papers of 
the Garde-Meuble's steward, brought together requests for payment, inventories of holdings in precious gems, and various extracts from the royal account books. The fact that these assorted papers were reunited and archived together clearly expresses the prevailing attitude of the time and the importance that these documents held for the service of the Ministry of Foreign Affairs.

Clearly intended to be consulted, or at least offering the advantages of classification, the volumes of the Présents $d u$ roi each carry an alphabetical index that allows readers quickly to locate themselves and to find what they are seeking easily. Each volume includes a general table of contents. Their elaboration is admittedly summary, separated into chapters by country, by subject, by occasion, and by recipient, allowing a linear reading.

These tables seem close to the description that Abbot Joachim Le Grand made in his answer to Colbert de Torcy about the exercises of the political academy, on the subject of indexes to historical works:

As for the tables of contents, more of several types must be done beyond the kind that appear at the beginning of several volumes[:] it is necessary to make alphabetical tables that include all the subjects such as, for example, "Audience," in order to mark all the audiences that one finds in the dispatches, [and] for example, "Baptisms," in the same manner. ${ }^{26}$

The result of this diligence is volumes that are easier to consult than a pile of accounting records, even classified and bound, as was the case for the journals or books of the king's precious gems. The latter, originating with the guardian or steward of those stones, presented documentation that served as a basis for the volumes listing gifts offered by the king.

Was there a model for establishing this type of document? Gaspard Moïse Augustin de Fontanieu (1694-1767, a government official who gathered and annotated documents related to French history, now at the Bibliothèque Nationale de France) wrote that "it was the responsibility of [Jean-Baptiste] Colbert [chief minister of Louis XIV] to organize into one body the scattered parts of the riches of the throne in this category and to make formal inventories ... that would assure an economy of use." 27 He remarked that Colbert kept the originals of the inventories of the Houses of Burgundy and of Austria in his library (which then passed into that of the king), and added that "it is almost necessary to believe that the knowledge that he took from these inventories gave him models for those he had projected for France."28 Fontanieu continued, writing 
that "on the example" of these inventories, "Monsieur Colbert made it understood in those [inventories] of the king that several types of furniture had been diverted from them, either in part or all together," and that "it was the same with the precious gems." 29

Fontanieu went on that the gems "were not included in the general inventory, a separate inventory of them was made and the keeping of it was entrusted not to the general steward but to the very keeper and general controller of furniture."30 In 1709 the responsibility was removed from the keeper in place, ${ }^{31}$ "for a not very honorable reason," and it was entrusted to an officer "who was not attached to the Garde-Meuble," and that "since then [the gems] have not been returned [to the GardeMeuble]."32

\section{An Organization à la Colbert}

The Présents $d u$ roi includes journals and large books listing precious gems. Six volumes bound in white parchment are held in the archives of the Foreign Affairs Ministry. The volumes represent the special guardianship of these gems.

It was at the suggestion of the Minister of State Colbert, and according to his methods, that, beginning in 1664, "accounts of the king's precious gems" were instituted. These livres de rencontre, or account books, contain all of the inventories of royal gems: diamonds, pearls, rubies, aquamarines, amethysts, topazes, emeralds, sapphires, garnets, hyacinths, peridots, opals, and other gem stones, carefully recorded..$^{33}$ Colbert instituted its procedures and daily routines by the keeping of a journal initialed by the guard. Using this journal, the steward "recorded in the margins of the last inventory all of the necessary deposits and withdrawals." 34 Among the papers inventoried in 1709 at the home of Gédéon Berbier du Metz, the director of the Garde-Meuble of the Crown, there is mention of "thirteen registers in paper covered with parchment of different sizes serving for the king's precious gems, begun the first of July 1669, and finished last October 20, of which five are completed, approved, and signed by the king and the eight others incomplete." 35 The volumes included in the "Presents" section of the Mémoires et documents, France series correspond to this description; they are the journals and large books of precious gems. ${ }^{36}$

In the series Mémoires et documents, France is an accounting document that must have been one of the sources for the Dubois volume. It is the Grand Livre pour les pierreries commencé le 15ème novembre 1677,37 a title engraved in the parchment binding. A note added in ink indicates 
it was "finished on September 1, 1684," and another on the back cover signals that it concerns the "sixth register or Grand Livre of 1677." This last inscription tells about the management of the accounts of presents given, recorded in "registers" or "books," which "are also called registers and public papers." 38 The inscription gives them a numerical order, signifying thereby that they belong to a series of methodical registering, managed by a steward or garde des livres (keeper of the books).

These books, or registers, are broken down into an "Inventaire" (Inventory), that is, "a description, status and accounting made in writing," 39 of what already belongs to the "fonds restant" (remaining holdings), plus that which was added to it, forming the "Recette" (Receipt). This receipt in fact constitutes a budget (a term that appears only at the end of the eighteenth century) on which it was possible to balance the "Dépenses" (Expenditures), that is, the "États de paiement" (Statements of payment), or the statements of orders for payment sent to the gold and silver merchants. At the end of the calculations, a "Result of the Receipt and expenditure" was signed by the king. 40

In the "Livre de rencontre" (account book), inventories of items on hand (in stock, paid for, but not yet presented or used) are added for a "Mémoire," that is, an accounting element that is simply narrative, where there is no sum to dispense. ${ }^{41}$ A general "Inventory" of the king's precious gems is established, carried into the "livre de rencontre" and "recorded in detail" in "another account book" and in a "journal" (day book), the "journal" being "a memoir of that which happens each day." 42

In 1684, Louis XIV declared: "I would be pleased if Du Metz continued to take care as he has done up until now of the holdings in precious gems and of their distribution following my orders and that in the future he leaves in the hands of the silversmiths and goldsmiths and jewelers only those [gems] that will be put into use." 43 As has been noted, at the beginning of the 1670 s, the stewardship of the precious gems was removed from the Garde-Meuble and transferred to the jeweler-inordinary of the king ("garde des pierreries" or keeper of the precious gems). 44 Was the "garde des pierreries" also the "garde des livres" (keeper of the books), and did he take care of titles, papers, and registers? ${ }^{45}$ In 1725, Le Fèvre, "garde des pierreries des présents du roi" (keeper of the gifts of the king's precious gems), accused the jeweler Laurent Rondé of combining the roles of dealer and recorder of the registries of gifts. ${ }^{46}$

On August 3, 1686, Colbert asked Clairambault to deliver "to M. de Montarsy all of the papers concerning the Inventory of the precious gems of the Crown." ${ }^{4}$ (See Fig. 5 for an example of a typical precious gift presented to an ambassador, called a "boîte à portrait," mounted by either 


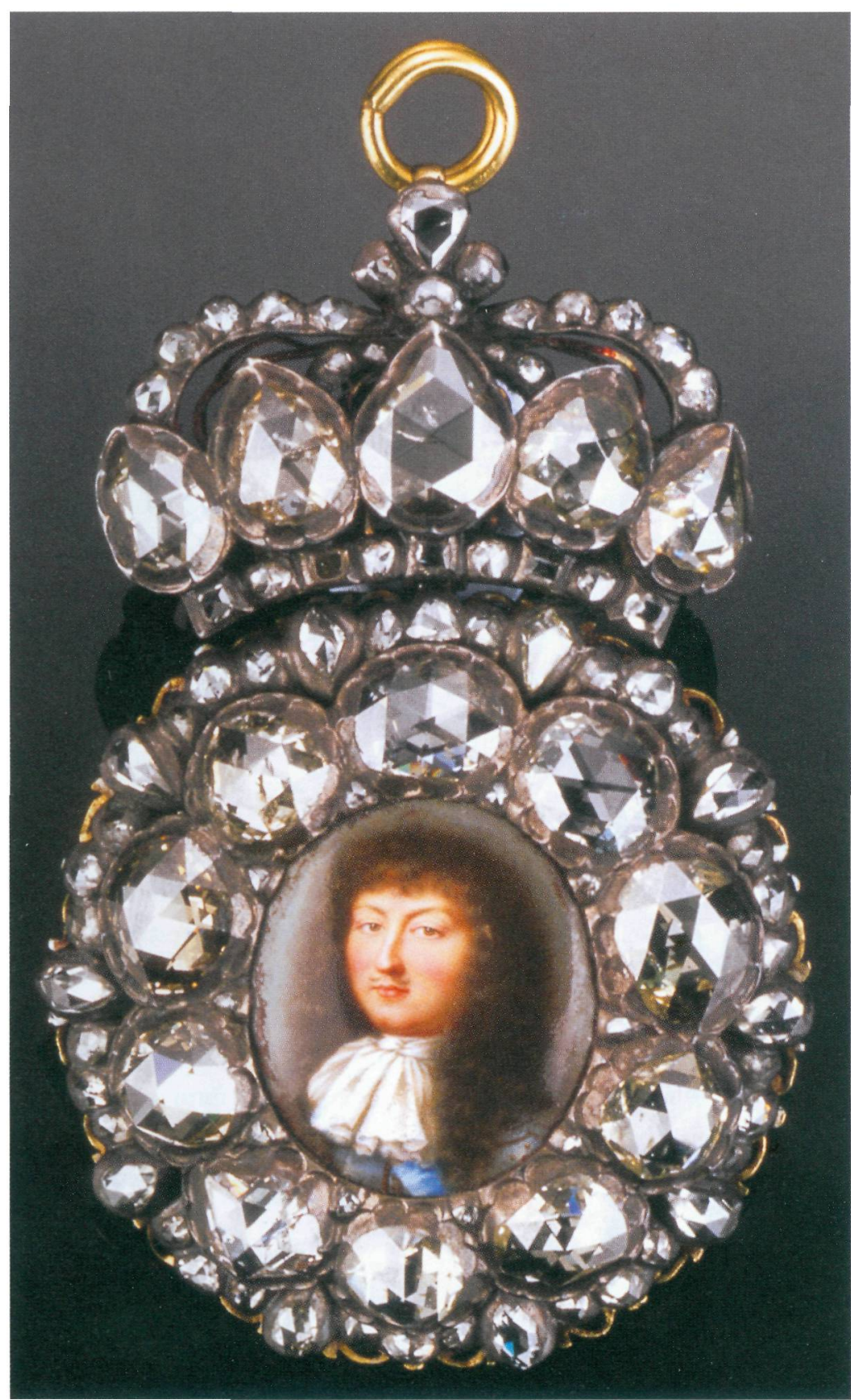

FIGURE 5

Pendant with portrait of Louis XIV by Jean I Petitot, mounts by Pierre or Laurent Le Tessier de Montarsy, Paris, c. 1680-1685. Cipher of Louis XIV on reverse. Silver-gilt, gold, enamel, rose-cut diamonds. Height 7.2 , width $4.6 \mathrm{~cm}$. Private collection.

Pierre Le Tessier de Montarsy or his son Laurent. Such a present was given to an ambassador when he returned to his country, meaning that he had been successful in his duty.) The scholar Michèle Bimbenet-Privat recently distinguished "this collection of precious gems" from the col- 
lection of the crown jewels, inalienable property of the king, 48 from the gold from the "décharge" (discharge) "of stones, mounted or not," and from the gold and silver objects cited in the margins of the "Journaux des pierreries du roi" (Journals of the king's precious stones) held in the archives of the Ministry of Foreign Affairs. ${ }^{49}$

\section{Conclusion}

If a simple justification is needed for the composition of this type of volume at the end of Louis XIV's reign, it certainly must be found in the preface of the volume (of unknown authorship) held in the French manuscripts department of the Bibliothèque Nationale de France:

The King's magnanimity has been and still is so great through the gifts and presents that he has offered and still offers to all the princes and potentates of all of Europe, [and] not only to them personally. They have also been extended to their ambassadors and envoys, either precious gems, furniture and gold and silver dishes, or ornaments for churches. The king did not stop there; he wished that the officers of his household, [and] those of the army and the marines would also enjoy them. ${ }^{50}$

Because the French king's presents were the most magnificent, their history had to be recorded. Perhaps at the same time such a record would serve as a model or a reference for future historical occasions. Of course, these presents also represent an important financial investment. They were the trademark of a government, as Voltaire made clear. Whatever the case, the tradition was established from then on to list royal presents together in a volume, and this continued until the end of the Ancien Régime. The volumes of gifts constitute, then, a form of economic record.

NOTES

1. François-Marie Arouet, called Voltaire, Le siècle de Louis XIV (first pub. Leipzig, 1752), in Voltaire, oeuvres historiques, ed. René Pomeau (Pléiade ed., Paris: Gallimard, 1957), chap. 25, pp. 911-12. "Ce qui lui donna dans l'Europe le plus d'éclat, ce fut une libéralité qui n'avait point d'exemple.... Les présents faits dans les pays étrangers furent si considérables que Viviani fit bâtir à Florence une maison des libéralités de
Louis XIV. Il mit en lettres d'or sur le frontispice: Aedes a deo datae, allusion au surnom de Dieudonné, dont la voix publique avait nommé ce prince à sa naissance."

2. Abraham de Wicquefort, L'ambassadeur et ses fonctions (1676; Cologne, 1690), vol. 1, 449.

3. Antoine Furetière, Dictionnaire universel (The Hague, 1690), vol. 3, s.v. "Présent." 
4. Ministère d'Affaires Etrangères, Paris (hereafter MAE), Mémoires et documents, France (Présents du roi, vol. 1), 2037. The present essay is derived from the author's critical edition of this volume, now in progress.

5. MAE, Mémoires et documents, France, 2037 2098. This numbered series includes volumes of lists of gifts, sometimes in two copies, as well as registers and account books. Gifts made during the reigns of Louis XV and XVI are recorded as well but are not the subject of this author's study.

6. The work of Armand Baschet (Prime Minister of France in the late nineteenth century) should be acknowledged here. He was the first, in the 1880s, to look through the archives of the Ministry of Foreign Affairs seeking documents about their creation in order to establish their history.

7. The author is continuing her research in this area and will present conclusions in her doctoral dissertation.

8. Isabelle Nathan studied the importance of these bindings in her article, "Les archives anciennes du ministère des Affaires étrangères," in L'invention de la diplomatie, ed. Lucien Bély (Paris, 1998), 193. 204.

9. Nathan, "Les archives anciennes," 196, n. 2.

10. Bibliothèque Nationale de France (hereafter BNF), Ms. Fr. 14112: “Un particulier s'est proposé sur les mémoires qu'il a recueillis s'étant trouvé en place d'en faire deux volumes. Qui commencent dès l'année 1669 jusque et compris la présente 1714. Et comme il y est encore, il les augmentera de ce qui viendra à sa connaissance."

11. Bibliothèque de l'Arsenal, Ms. 4267. This description comes from Henri Martin, Catalogue des manuscrits de la Bibliothèque de l'Arsenal (Paris, 1888), vol. 4, 344, and vol. 8, 193-95, 298-99.

12. Antoine-René de Voyer d'Argenson, marquis de Paulmy (1722-1778).

13. One of the best studies of Colbert's centralization of French government is Jean-Pierre Samoyault's Les bureaux du secrétariat d'Etat des Affaires étrangères sous Louis XV (Paris, 1971).

14. "Sa Majesté voulut bien, sur ce que je lui représentai, donner un lieu au Louvre pour y faire un dépôt de tous les papiers importants des Affaires étrangères"; unpublished journal of Jean-Baptiste Colbert de Torcy, December 22, 1709, quoted in Ministère des Relations extérieurs, Les archives $d u$ Ministère des Relations extérieures depuis les origines, vol. 1 (Paris, 1985).
15. Armand Baschet, Histoire du dépôt des archives des Affaires étrangères (Paris, 1887), 112-15: "tous les titres et papiers qui concernent la charge de ministre d'Etat des Affaires étrangères."

16. Ibid., 101: "Torcy attachait à la création du dépôt des Affaires étrangères une idée capitale, qui était celle d'une école de négotiations, celle d'un centre d'études aussi spécialement appliquées à la politique qui pourrait l'être à l'art de la guerre une école militaire."

17. This designation appears in BNF, Clairambault 519, in the response that Abbot Le Grand made to Torcy, fol. 439.

18. Baschet, Histoire du Dépot, 152-57; and BNF, Clairambault 451.

19. Samoyault, Les bureaux du secrétariat d'Etat des Affaires étrangères sous Louis XV, 92.

20. MAE, Correspondance Politique, Venise, vol. 175, fols. 15 and 167.

21. As cited by Baschet, Histoire du dépôt, 173-74: "Je vous prie de ne pas oublier de marquer s'il y a un dépôt où l'on garde les papiers qui regardent les affaires de la République a avec les étrangers et de me donner le détail de tout ce qui y a rapport, c'est-à-dire l'ordre qui y est observé, à qui ce dépôt est confié, quels sont les officiers qui en ont soin et tout ce qui peut donner une description exacte."

22. Philippe Lauer's biography of Clairambault and his history of the collection appear in Philippe Lauer, Catalogue des manuscrits de la Collection Clairambault (Paris, 1923-1924), vol. 3, intro., n.p.: "Né à Asnières en 1651, débuta à la bibliothèque de Colbert, puis à celle du Roi, sous la direction de Pierre Carcavy. En 1676, puis 1683, il fut chargé de prêter son concours à Bossuet et à Fénelon pour l'instruction historique du fils et petit-fils de Louis $\mathrm{XIV}$, et il entreprit une compilation. Chercheur et compilateur, ses volumes, qui constituent sa collection aujourd'hui à la bibliothèque nationale, comptent des extraits pris dans les manuscrits de la bibliothèque du Roi, mais aussi des copies ou extraits accompagnés de documents originaux des XVIe et XVIIe siècles.... Le renom mérité qu'il s'acquit le désigna en 1698 pour la charge de généalogiste des Ordres du Roi.... Il excellait à disposer les documents en recueils suivant le plan le plus propre à en faciliter l'utilisation."

23. BNF, Clairambault 499, fol. 453 r.

24. MAE, Mémoires et documents, France, 20402042.

25. BNF, Fr. 14112, Avertissement.
26. BNF, Clairambault 519, fol. 449r-v, on article 12: "Quant aux tables il en faut faire de plus d'une sorte outre celles qu'on trouve à la tête de plusieurs volumes, il est nécessaire d'en dresser d'alphabétiques qui comprennent toutes les matières comme par exemple 'Audience,' marquer toutes les audiences qu'on trouvera dans les dépêches, exemple 'Baptêmes,' de la même manière."

27. Portefeuille Fontanieu, BNF, Nouvelles Acquisitions Françaises (hereafter NAF) 7859, fols. 212v-213r: "il était réservé à Colbert de rassembler en un corps les membres épars des richesses du trône en ce genre et d'en faire des inventaires en forme...qui en assurassent l'économie dans l'usage."

28. Ibid., fol. 213v: "il est presque nécessaire de croire que la connaissance qu'il prit de ces inventaires lui fournit les modèles de ceux dont il avait le projet pour la France."

29. Ibid., fol. 217r-v: "Monsieur Colbert fit comprendre dans ceux du roi plusieurs espèces de meubles qui en ont été distraits depuis soit en tout soit en partie"; "en a été de même des Pierreries."

30. Ibid., fol. 218r: "ne furent point comprises dans l'inventaire général, il en fut fait un inventaire particulier et la garde en fut confiée non au garde général mais à l'intendant même et contrôleur général des meubles."

31. The man removed from his post was Berbier Gédéon du Metz (1626-1709).

32. Portefeuille Fontanieu, BNF, NAF 7859, fol. 219r: "par une raison peu honorable"; "qui n'était point attaché au Garde-Meuble"; “depuis elles n'y sont point revenues."

33. MAE, Mémoires et documents, France, 2038, 2040-2046.

34. Portefeuille Fontanieu, BNF, NAF 7859, fol. 224r: "opère en marge du dernier inventaire toutes les charges et décharges nécessaires."

35. Stéphane Castelluccio, Le Garde-Meuble de la Couronne et ses intendants du XVIe au XVIIle siècle (Paris, 2004), 92: "treize registres en papier couverts de parchemin de diverses grandeurs servant pour les pierreries du Roy, commencé le premier juillet 1669 et fini le 20 octobre dernier, dont cinq sont arrêtés, approuvés et signés par le Roy et les huit autres non arrêtés."

36. MAE, Mémoires et documents, France, 2040 2042.

37. Ibid., 2042. 
38. Furetière, Dictionnaire universel, vol. 2, s.v. "Livre."

39. Ibid., s.v. "Inventaire": "une description, un état et dénombrement qui se fait par écrit."

40. MAE, Mémoires et documents, France, 2042.

41. Furetière, Dictionnaire universel, vol. 2, s.v. "Mémoire."

42. Ibid., s.v. "Journal."

43. MAE, Mémoires et documents, France, 2042, fol. 122r-v. Accounts approved by the king on August 31, 1684. "Je veux que Du Metz continue de se charger comme il a fait jusques à présent du fonds des pierreries et de la distribution suivant mes orders et qu'à l'avenir il ne laisse ès mains des orfèvres et joaillers que celles qui seront à mettre en oeuvre."

44. Stéphane Castelluccio, Les collections royales d'objets d'art, de François Ier à la Révolution (Paris, 2002), 232, n. 6 .

45. Furetière, Dictionnaire universel, vol. 2, s.v "Livre."

46. Michèle Bimbenet-Privat, "Les pierreries de Louis XIV: Objets de collection et instruments politiques," in Études sur l'ancienne France offertes en hommage à Michel Antoine, ed. Bernard Barbiche and Yves-Marie Bercé (Paris, 2003), 87.

47. BNF, NAF 9565, fol. 170. Laurent Le Tessier sieur de Montarsy (1661-1684), jeweler-in-ordinary to the king, had lodgings in the Galeries du Louvre.
48. Michèle Bimbenet-Privat, Les orfèvres et l'orfèrrerie de Paris au XVIIe siècle (Paris, 2002), 401.

49. MAE, Mémoires et documents, France, 2040. 2042.

50. BNF, Fr. 14112. "La magnificence du Roi a été et est encore si grande par ses dons et présents qu'il a fait et fait actuellement à tous les princes et potentats de toute l'Europe [et] non seulement à leurs personnes; ils se sont répandus jusqu'à leurs ambassadeurs et envoyés tant en pierreries, meubles et vaisselles d'or et d'argent qu'en ornements d'églises. Il n'en est pas resté là; il a voulu que les officiers de sa maison, [et] ceux de terre et de marine s'en ressentissent." 